Dasman Lanin, Syamsir, Boni Saputral Model Pelayanan Pemerintah Daerah yang Memuaskan Pelanggan Internal dan Eksternal Berbasis Total Quality Management

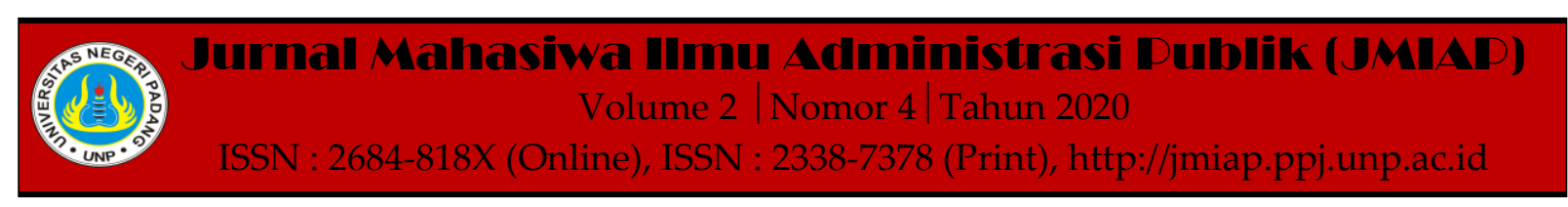

\title{
MODEL PELAYANAN PEMERINTAH DAERAH YANG MEMUASKAN PELANGGAN INTERNAL DAN EKSTERNAL BERBASIS TOTAL QUALITY MANAGEMENT
}

\author{
Dasman Lanin ${ }^{1(a)}$, Syamsir $^{2(b)}$, Boni Saputra ${ }^{3(c)}$ \\ ${ }^{1}$ Jurusan Ilmu Administrasi Negara, Universitas Negeri Padang \\ ${ }^{2}$ Jurusan Ilmu Administrasi Negara, Universitas Negeri Padang \\ a)dasman@fis.unp.ac.id, ${ }^{b)}$ syamsir@fis.unp.ac.id, ${ }^{c)}$ bonisaputra@fis.unp.ac.id
}

\begin{abstract}
Simultaneously, service quality as measured by customer satisfaction (internal and external) has not been the focus of service improvement in Indonesia, the new Menpan and Bureaucratic Reform measure the Community Satisfaction Index (IKM) for external customers. In this study, equity theory is assumed to be a bridge between internal and external customer satisfaction. This study analyzes the level of differences in internal and external customer satisfaction on service transactions and analyzes the effect of internal customer satisfaction on service transactions and the effect of service transactions on external customer satisfaction. Service transactions use indicators of delivery, timeliness, information, professionalism, staff attitudes, and organizational politics. The final objective of this research is to create a quality local government service model through the Total Quality Management (TQM) approach. This research was conducted at RSUD Padang Panjang using an asocial quantitative approach. Data collection used a Likert scale questionnaire which had previously been tested for validation and reliability both in content and in empirical test items. A valid and reliable questionnaire was then used to collect data samples taken using stratified proportional random sampling technique, using the Slovin formula (error 2\%) obtained a sample of 201 internal respondents and 956 external respondents. Data were analyzed by regression and t-test that had previously been tested classical assumptions. The results showed that there is a significant effect of internal customer satisfaction on service transactions and the effect of service transactions on external customer satisfaction. While the t-test results emphasize the level of significant differences in information and indicators of organizational politics.
\end{abstract}

Keywords : Customer Satisfaction, Equity, Total Quality Management, Service Transactions

Corresponding author. Email.dasman@ fis.unp.ac.id

How to cite this article. Lanin, D., Syamsir \& Saputra, B. (2020). Model Pelayanan Pemerintah Daerah yang Memuaskan Pelanggan Internal dan Eksternal Berbasis Total Quality Management. Jurnal Mahasiwa Ilmu Administrasi Publik (JMIAP) Jurusan Ilmu Administrasi Negara Fakultas Ilmu Sosial Universitas Negeri Padang, Volume 2 (4), Hal. 53-61.

http://jmiap.ppj.unp.ac.id

ISSN : 2684-818X (Online), ISSN : 2338-7378 (Print)

Copyright@2020. Published by Labor Jurusan Ilmu Administrasi Negara FIS UNP, Padang

53 | Jurnal Mahasiwa Ilmu Administrasi Publik | Volume 2 | Nomor $4 \mid$ Tahun 2020 | (Hal. 53-61) 


\section{PENDAHULUAN}

Kualitas pelayanan yang diukur dengan kepuasan pelanggan (internal dan eksternal) secara serentak belum menjadi fokus perbaikan pelayanan di Indonesia, Menpan dan Reformasi Birokrasi baru mengukur Indeks Kepuasan Masyarakat (IKM) untuk pelanggan eksternal saja. Dwiyanto (2012) menilai bahwa perbaikan pelayanan publik yang dilakukan pemerintah belum memiliki dampak yang berarti, karena masih digerogoti oleh birokrasi yang sangat korup, dan tidak profesional. Sementara, pelayanan publik yang substantif adalah yang mampu melahirkan kepuasan masyarakat sebagai pelaksanaan fungsi dasar dan kewajiban pemerintah daerah. Hal ini, mungkin disebabkan karyawan (pelanggan internal) belum mampu menghadirkan kualitas dan profesionalismenya dalam mengeksekusi pelayanan tersebut. Persoalannya, salah satunya disebabkan, mereka (pelanggan internal) belum memiliki kepuasan pula dalam menjalankan tugas yang diembannya.

Menurut konsep TQM bahwa kepuasan pelanggan internal (employee) adalah variabel yang berpengaruh secara linear pada kehadiran kepuasan pelanggan eksternal atau masyarakat (Hensler and Brunell, 2003), dan dalam pelayanan publik juga ditegaskan oleh Harwick and Russell (2007:499) dari Total Quality Performance Research Institute bahwa untuk pelayanan yang lebih baik dengan pembayaaran pajak yang lebih sedikit sangat ditentukan oleh faktor kepuasan pelanggan internal (karyawan). Hal ini juga didukung oelh penelitian Harwick dan Russell (2003), bahwa logika TQM jelas menunjukkan bahwa kinerja tidak memiliki hubungan linear dengan input atau sumberdaya tetapi kritis tergantung pada cara pelayanan publik diatur dan dilembagakan. TQM sebagai metodologi aksi merombak "bisnis biasa" menjadikan kontrol bukan sebagai penyebab, tetapi sebagai akibat kapasitas yang dilembagakan dalam memenuhi dan melampaui harapan pelanggan.
Keragu-raguan ini dicoba dikonsepkan oleh Hensler dan Brunell (2007: 167) bahwa keduanya punya link dalam memberikan keuntungan bisnis, seperti rantai keterkaitan yang dikemukakanya dalam bagan di bawah.

\section{Gambar 1. Model The Service Profit Chain}

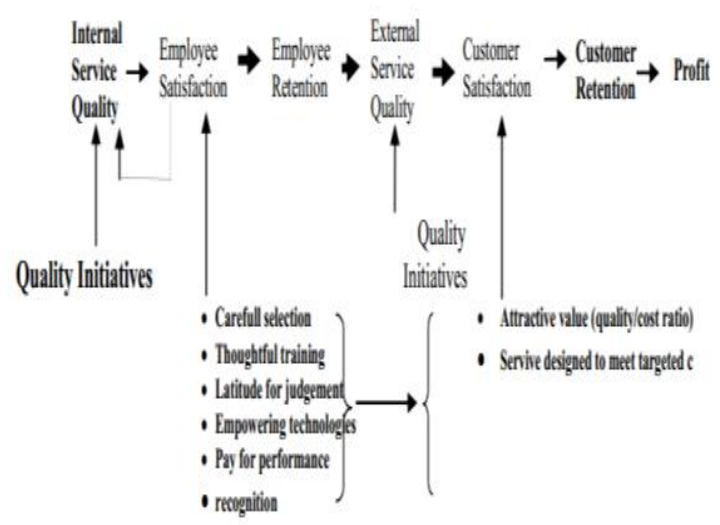

Sumber : Harwick dan Russell, 2003

Berdasarkan model yang dikemukakan oleh Harwick dan Russell di atas, bahwa keterkaitan kepuasan pelanggan internal dengan eksternal, antara employee satisfaction dengan custumer satisfaction yang diantarai employee retention dan external service quality, menjelaskan pengaruh kepuasan pelanggan internal terhadap kepuasan pelanggan eksternal sepertinya signifikan. Peneliti yakin bahwa kepuasan pelanggan internal berpengaruh terhadap kepuasan pelanggan eksternal. Jadi, dapat disimpulkan, TQM layak dikembangkan dalam pelayanan publik melalui penelitian yang terus menerus supaya mendapatkan teoritikal yang kuat dan adaptif dengan budaya Indonesia.

Sebenarnya, reformasi pelayanan publik termasuk pelayanan kesehatan di rumah sakit, belum banyak menghasilkan perubahan, meskipun dilakukan secara terus menerus oleh pemerintahan daerah, baik berdasarkan UU No. 22 tahun 1999 tentang Otonomi Daerah, UU No. 32 tahun 2004 tentang Pemerintahan Daerah ataupun UU No. 25 tahun 2009 tentang Pelayanan Publik serta SK Menpan dan RB tentang IKM. Hasil penelitian tentang IKM bidang kesehatan di Sumatera Barat umumnya dan 
Kota Padang Panjang khususunya, ternayata menunjukkan indikasi yang demikian. Hasil penelitian Dasman Lanin dan Adil Mubarak (2010) mengukur dengan teori Ryzin, \& Gregg (2005) yang dikenal dengan the Expectancy Disconfirmation Model of Citizen Satisfaction with Local Government dan Dasman Lanin (2015) menemukan bahwa umumnya mayarakat belum puas dengan pelayanan kesehatan kabupaten/kota Sumbar, dengan menggunakan pengukuran IKM Menpan dan RB. Indeks Kepuasan Masyarakat dalam pemenuhan pelayanan kebutuhan dasar masyarakat (pendidikan, kesehatan dan sosial kesejahteran) di Sumatera Barat membuktikan hasil yang tergolong rendah, sementara itu untuk kepuasan masyarakat dibidang layanan kesehatan khususnya pada Kota Padang Panjang menunjukkan hasil hanya 0,6 \% masyarakat padang panjang yang merasa puas dengan pelayanan kesehatan yang ada di kota tersebut. Hal ini menggambarkan bahwa masyarakat Kota Padang Panjang secara keseluruhan masih merasa belum puas dengan pelayanan kesehatan yang diterima. Pelayanan Kesehatan di Kota Padang Panjang merupakan salah satu sektor pelayanan publik yang diunggulkan dan dicantumkan dalam Renstra 2008-2013 sebagai program dan rencana yang the best practice di kota ini (Dasman Lanin, 2012). Penelitian lainnya yang telah dilakukan oleh Dasman Lanin terkait tentang kepuasan adalah Dasman Lanin (2008) menemukan influencing manager roles toword increasing public service on local government dengan signifikansi yang meyakinkan. dan kontribusinya 7,9\%. "As for external role construct of manager used Mintzberg's Theory and construct of citizen satisfaction used Expectancy Disconfirmation the Model Citizen Satisfaction Local Government of Ryzin \& Gregg Its result showed correlation which was significant'. Dasman Lanin (2010) temuan penelitian ini menyimpulkan bahwa organisasi politik internal berkorelasi negatif terhadap kepuasan masyarakat. Kepuasan masyarakat dengan pelayanan kesehatan yang disediakan pemerintah Kota menjadi ukuran atau penilaian ekstemal efektifitas atau tidaknya pelaksanaan program unggulan tersebut.

Berdasarkan kondisi pelayanan publik yang belum memuaskan di atas, bahkan cenderung tidak responsif dan tidak professional menurut Kurniawan \& Puspitosari (2010) berakibat kepada para pelanggan ekternal, mereka dihadapkan kepada dua pilihan yang memaksa (coercion) yaitu; (1) untuk menggunakan secara tidak mengenakkan (dissatisfaction) atau (2) tidak menggunakan sama sekali (very dissatisfaction) karena tidak setuju dengan karakteristik pelayanan yang desediakan pemerintah tersebut.

Ketidakprofesionalan itu diasumsikan, salah satunya disebabkan oleh ketidak-puasan karyawannya. Karena menurut pendekatan TQM kedua pelanggan, baik internal (pemberi layanan) ataupun eksternal (pengguna layanan) punya link yang erat. Dalam TQM kepuasan karyawan menentukan kepuasan pelanggan eksternal (Schlenger and Hallowell, 1996). Namun secara akademik belum tereksplorasi teori yang menghubungkan kedua kepuasan pelanggan ini. Disinilah posisi penelitian ini dilakukan, dengan menawarkan teori Equity, yang diasumsikan dapat menghubungkan secara konseptual kedua pelanggan tersebut. Kondisi inilah yang memicu peneliti fokus pada masalah berikut.

Bagaimana model pelayanan pemerintah daerah yang berkualitas (memuaskan pelanggan internal dan eksternal) berbasis TQM diberbagai sektor pelayanan public? Bagaimana mendesain model yang mengintegrasikan (sintesiskan) teori Equity sebagai teori kepuasan pelanggan (internal dan ekternal) dengan pendekatan TQM berdasar pengalaman pelayanan publik sebuah organisasi publik (RSUD Padang-panjang)?

\section{METODE PENELITIAN}

Metode penelitian mengunakan pendekatan kuantitatif asosiatif, jenis asosiatif karena penelitian ini menghubungkan dua variabel atau lebih (Ginting, 2008). Subjek penelitian yaitu 
pasien Rumah Sakit Umum Daerah Padang Panjang. Pengumpulan data menggunakan angket berskala likert yang sebelumnya telah di uji validasi dan reliabilitas baik kontennya maupun uji empirik itemnya. Angket yang valid dan reliabel kemudian digunakan untuk pengumpulan data pada sampel yang ditarik dengan teknik stratified proportional random sampling, dengan menggunakan rumus Slovin (eror 2\%) dari jumlah populasi sebanyak 61.520 diperoleh sampel sebanyak 201 responden internal dan 956 responden ekternal. Data dianalisis dengan regression, dan $t$-tes yang sebelumnya juga sudah diuji asumsi kalsiknya. Uji prasyarat asumsi klasik terdiri dari: 1) Uji Normalitas; 2) Uji Linearitas; 3) Uji Heterokedasitas; dan 4) Uji Multikolinearitas. Variabel dan indikator yang digunakan dalam penelitian ini akan terlihat seperti tabel di bawah ini:

\section{Tabel 1. Variabel dan Indikator Penelitian}

\begin{tabular}{|c|c|c|}
\hline Variabel & Sub Varbel & Indikator/Deskriptor \\
\hline \multirow[t]{2}{*}{$\begin{array}{l}\text { Kepuasan } \\
\text { Pelanggan }\end{array}$} & Internal & $\begin{array}{l}\text { Pelanggan menilai nisbah hasil yang mereka } \\
\text { peroleh dan masukan yang mereka berikan }\end{array}$ \\
\hline & Eksternal & $\begin{array}{l}\text { berbanding dengan hasil dan masukan orang lain } \\
\text { dalam transaksi pelayanan. }\end{array}$ \\
\hline \multirow{6}{*}{$\begin{array}{l}\text { Variabel Transaksi } \\
\text { pelayanan Kepuasan } \\
\text { Pelanggan Internal } \\
\text { Kepuasan Pelanggan } \\
\text { Eksternal }\end{array}$} & Delivery & $\begin{array}{l}\text { 1) Hasil Akhir; 2) Cara menjaga janji; 3) Cara } \\
\text { menangani problem; 4) Komitmen pada pelanggan }\end{array}$ \\
\hline & Timeliness & $\begin{array}{l}\text { 1) Masa tunggu; 2) Lama penyelesaian; } \\
\text { 3) frekwensi kontak; 4) Lamanya penjelasan. }\end{array}$ \\
\hline & Information & $\begin{array}{l}\text { 1) Keakurasian; 2) Kekomprehensifannya; } \\
\text { 3) Kesegeraannya; 4) Keaktualan. }\end{array}$ \\
\hline & Profesionalism & $\begin{array}{l}\text { 1) Staf yang kompeten; 2) Staf yang berperilaku } \\
\text { adil; 3) Berpengetahuan dan terlatih. }\end{array}$ \\
\hline & Staff Attitude & $\begin{array}{l}\text { 1) Ramah dan sopan; 2) Simpatik; 3) Jujur, tulus } \\
\text { dan tidak memihak; 4) Hubungan yang baik dan } \\
\text { sama; 5) Menghindari moral yang kurang baik; } \\
\text { 6) Adaptif dan berfikir strategis; 7) Moralis dan } \\
\text { berbudi luhur. }\end{array}$ \\
\hline & $\begin{array}{l}\text { Organizational } \\
\text { politic }\end{array}$ & $\begin{array}{l}\text { 1) Tujuan untuk orang tertentu; 2) Pilih kasih; } \\
\text { 3) Terpengaruh tekanan politik; 4) Kompetisi klik; } \\
\text { 5) Penyimpangan organisasi; 6)Pembagian tugas } \\
\text { yang tidak jelas }\end{array}$ \\
\hline
\end{tabular}

Pada penelitian ini teori equity diasumsikan dapat menjadi jembatan antara kepuasan pelanggan internal dan ekternal. Sehingga konsepsi penelitian bertujuan untuk menganalisis pengaruh kepuasan pelanggan internal terhadap transaksi pelayanan dan pengaruh transaksi pelayanan terhadap kepuasan pelanggan ekternal serta menganalisis tingkat perbedaan dari sudut pandang kepuasan pelanggan internal dan ekternal terhadap transaksi pelayanan yang diberikan oleh peyanan publik di RSUD Padang Panjang. Sedangkan alur pikir kajian penelitian semakin jelas dengan memperhatikan diagram gambar di bawah ini:

\section{Gambar 2. Kerangka Analisis Penelitian}

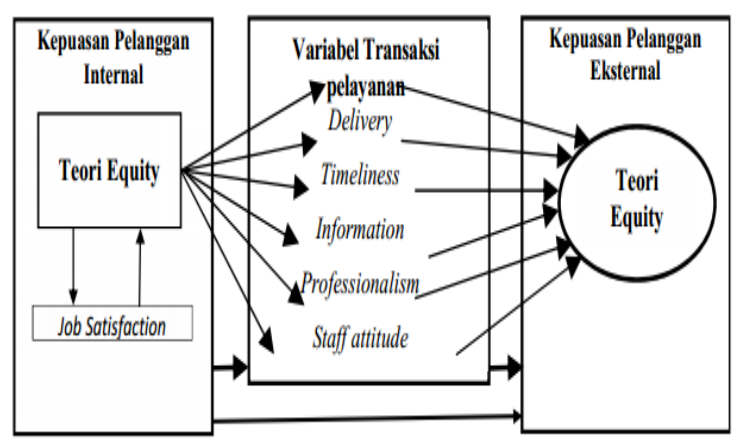

Menurut konsep TQM bahwa kepuasan pelanggan internal (employee) adalah variabel yang berpengaruh secara linear pada kehadiran kepuasan pelanggan eksternal atau masyarakat Ketika pelanggan internal merasakan tingkat kepuasan yang baik maka pelanggan internal akan memberikan transaksi pelayanan dengan baik kepada pelanggan eksternal, sehingga pelanggan akan merasa puas dengan pelayanan yang diberikan oleh pelanggan internal. Sehingga hipotesis dalam penelitian ini adalah 1) terdapat pengaruh kepuasan pelanggan internal secara signifikan terhadap transaksi pelayanan; 2) terdapat pengaruh transaksi pelayanan secara signifikan terhadap kepuasan pelanggan eksternal.

\section{HASIL DAN PEMBAHASAN Karakteristik Demografi Penelitian}

Demografi yang dimaksud adalah mencakup pelanggan internal dan eksternal yang diteliti. Pelanggan internal dan pelanggan eksternal dapat digambarkan secara menyeluruh dan umum dalam tabel berikut: 
Dasman Lanin, Syamsir, Boni Saputral Model Pelayanan Pemerintah Daerah yang Memuaskan Pelanggan Internal dan Eksternal Berbasis Total Quality Management

Tabel 2. Karakteristik Responden Pelanggan internal dan Eksternal

\begin{tabular}{|c|c|c|c|c|}
\hline \multirow{2}{*}{ Karakteristik } & \multicolumn{2}{|c|}{ Internal } & \multicolumn{2}{|c|}{ Eksternal } \\
\hline & $\mathrm{F}$ & Persentase & $\mathrm{F}$ & Persentase \\
\hline \multicolumn{5}{|l|}{ Jenis Kelamin } \\
\hline a. Laki-Laki & 88 & $43.8 \%$ & 427 & $44.7 \%$ \\
\hline b. Perempuan & 113 & $56.2 \%$ & 529 & $55.3 \%$ \\
\hline Jumlah & 201 & $100 \%$ & 956 & $100 \%$ \\
\hline \multicolumn{5}{|l|}{ Usia } \\
\hline a. Dibawah 20 Tahun & 1 & $0.5 \%$ & 74 & $7.7 \%$ \\
\hline b. 21.50 Tahun & 200 & 99.5 & 748 & $78,3 \%$ \\
\hline c. Diatas 50 Tahun & 0 & $0 \%$ & 134 & $14.0 \%$ \\
\hline Jumlah & 201 & $100 \%$ & 956 & $100 \%$ \\
\hline \multicolumn{5}{|l|}{ Cara bayar } \\
\hline a. Umum & 0 & $0 \%$ & 131 & $13.7 \%$ \\
\hline b. BPJS Mandiri & 32 & $15.9 \%$ & 352 & $36.8 \%$ \\
\hline c. BPJSPBI & 3 & $1.5 \%$ & 270 & $28.2 \%$ \\
\hline d. BPJS Non PBI & 166 & $82.6 \%$ & 197 & $20.6 \%$ \\
\hline e. Lainnya & 0 & $0 \%$ & 6 & $0.6 \%$ \\
\hline Jumlah & 201 & $100 \%$ & 956 & $100 \%$ \\
\hline \multicolumn{5}{|l|}{ Pendapatan } \\
\hline a. $<$ Rp. 1.000 .000 & 6 & $3.0 \%$ & 245 & $25.6 \%$ \\
\hline $\begin{array}{l}\text { b. Rp } 1.000 .001-R p . \\
\quad 2.500 .000\end{array}$ & 76 & $37.8 \%$ & 324 & $33.9 \%$ \\
\hline $\begin{array}{l}\text { c. } \operatorname{Rp} 2.500 .001-R p \\
4.000 .000\end{array}$ & 110 & $54.7 \%$ & 286 & $29.9 \%$ \\
\hline d. > Rp. 4.000 .001 & 9 & $4.5 \%$ & 101 & $10.6 \%$ \\
\hline Jumlah & 201 & $100 \%$ & 956 & $100 \%$ \\
\hline $\begin{array}{l}\text { Sumber: Hasil } \\
\text { diolah) }\end{array}$ & $\mathrm{Pe}$ & relitian & 2018 & (data \\
\hline
\end{tabular}

Berdasarkan tabel di atas dapat diketahui bahwa karakteristik demografi penelitian ini dapat dilihat dari jenis kelamin, usia, cara bayar dan pendapatan. Dilihat dari jenis kelamin, didominasi oleh perempuan dimana pelanggan internal ada sebesar $56.2 \%$ dan pada pelanggan eksternal ada sebesar $55.3 \%$. Sedangkan usia didominasi oleh usia 21 smpai 50 tahun baik pada pelanggan internal $(99.5 \%)$ maupun pada pelanggan eksternal yang berjumlah $78.3 \%$. Di lihat dari segi cara bayar, pada pelanggan internal didominasi oleh BPJS Non PBI $(82.6 \%)$ dan pada pelanggan eksternal didominasi oleh BPJS Mandiri (36.8\%). Adapun dari segi pendapatan, pelanggan internal lebih dominan berpendapatan 2.5 sampai 4 juta sebanyak $54.7 \%$ dan pendapatan pelanggan eksternal didominasi dengan pendapatan 1 sampai 2.5 juta sebanyak $33.9 \%$.

\section{Perbedaan Kepuasan Pelanggan Internal dan Eksternal Terhadap Variabel Transaksi Pelayanan}

Langkah awal dari pembuktian model yang dimuat dalam kerangka analisis penelitian adalah memastikan bahwa variabel transaksi pelayananan yang direncanakan, diuji terelebih dahulu kesamaan persepsi antara Pelanggan Internal dan persepsi Pelanggan Elsternal. Dalam melihat persamaan persepsi tersebut telah digunakan analisis $t$-test. Sedangkan variabel transaksi pelayanan yang dipersepsi kedua pelanggan itu adalah; (1) Penyerahan, (2) Waktu, (3) Informasi, (4) Profesionalisme, (5) Sikap Staf, dan (6) Politik Internal Organisasi.

Hasil analisis $t$-test, ternyata tidak semua variable transaksi pelayanan yang dipersepsi sama oleh pelanggan yang berbeda posisinya (internal dan eksternal). Untuk menjelaskan hal ini berikut dikemukakan hasil analisis data seperti yang telihat pada tabel di bawah ini:

\section{Tabel 3. Pandangan Pelanggan Internal} dan Eksternal

\begin{tabular}{|c|c|c|c|c|}
\hline Variabel/Indikator & Kelompok & N & Mean & $\mathrm{Sig}$, \\
\hline \multirow{2}{*}{ Penyerahan (delivery) } & Intemal & 201 & 3.6231 & \multirow{2}{*}{.172} \\
\hline & Eksternal & 956 & 3.6933 & \\
\hline \multirow{2}{*}{ Waktu (Timeliness) } & Intemal & 201 & 3.5498 & \multirow{2}{*}{.794} \\
\hline & Eksternal & 956 & 3.5553 & \\
\hline \multirow{2}{*}{ Informasi (Information) } & Intemal & 201 & 3.5373 & \multirow{2}{*}{.000} \\
\hline & Eksternal & 956 & 3.7262 & \\
\hline \multirow{2}{*}{$\begin{array}{l}\text { Profesionalime } \\
\text { (Professionalism) }\end{array}$} & Intemal & 201 & 3.7015 & \multirow{2}{*}{.828} \\
\hline & Eksternal & 956 & 3.6899 & \\
\hline \multirow{2}{*}{ Sikap Staf (Staff Atititude) } & Intemal & 201 & 3.6612 & \multirow{2}{*}{.318} \\
\hline & Eksternal & 956 & 3.6067 & \\
\hline \multirow{2}{*}{$\begin{array}{l}\text { Politikinternal Organissai } \\
\text { (Orramizantional Politicic }\end{array}$} & Intemal & 201 & 3.2164 & \multirow{2}{*}{.000} \\
\hline & Eksternal & 956 & 3.2533 & \\
\hline
\end{tabular}

Sumber: Hasil Penelitian 2018 (data diolah)

Berdasarkan tabel di atas dapat diketahui bahwa pandangan pelanggan internal dan eksternal tentang variabel transaksi pelayanan yang terdiri dari enam indikator 
Dasman Lanin, Syamsir, Boni Saputral Model Pelayanan Pemerintah Daerah yang Memuaskan Pelanggan Internal dan Eksternal Berbasis Total Quality Management

yang diselenggarakan oleh penyedia pelayanan di RSUD Padang Panjang ternyata terdapat dua indikator dari variabel transaksi pelayanan yang dinyatakan signifikan. Dinyatakan signifikan karena nilai sig. $<0.05$, yaitu indikator Informasi (Information) dan indikator Politik Internal Organisasi (Organizational Politic). Perolehan nilai signifikansi masing-masing indikator tersebut adalah 0.000 sehingga hal ini berarti bahwa berdasarkan uji persamaan dan perbedaan diketahui bahwa pandangan antara pelanggan internal dan pelanggan ekternal tentang faktor ketersediaan informasi (information) dan faktor politik internal organisasi (Organizational Politic) di RSUD Padang Panjang, terbukti bahwa kedua pihak pelanggan tersebut memiliki perbedaan yang berarti.

Informasi (information) yang disediakan RSUD Padang Panjang dilihat dari pihak pelanggan internal dan eksternal adalah kemudahan dan kemutakhiran informasi yang bermaanfaat bagi kedua pelanggan. Pandangan atau persepsi pelanggan internal dan pelanggan eksternal tentang Informasi (information) yang diberikan kepada pelanggan. Sedangkan keberadaan politik organisasi pada pelayanan RSUD Padang Panjang dilihat dari pihak pelanggan internal dan eksternal adalah seperti keadaan persaingan antar click yang hadir dalam pelayanan di RSUD tersebut.

\section{Pengaruh Kepuasan Equitas Pelanggan Internal terhadap Variabel Transaksi Pelayanan}

Pengaruh kepuasan eguitas yang dimiliki pelanggan internal menunjukan pengaruh yang dapat memprediksi kondisi berbagai variabel yang menjadi pengamatan kita dalam penelitian. Dalam penelitian ini telah dilihat pengaruhnya terhadap enam variabel transaksi pelayanan seperti yang telah dikemukakan di atas. Olah data statistik pada penelitian ini dilakukan dengan mengunakan analisis regresi linear berganda. Ringkasan hasil uji regresi dapat dilihat pada tabel di bawah ini:
Tabel 4. Hasil Uji Regresi Pengaruh Equity Satisfaction Pelanggan Internal terhadap Variabel Transaksi Pelayanan

\begin{tabular}{|c|c|c|c|c|}
\hline Model & $R$ & RSquare & $\begin{array}{l}\text { Adjusted } \\
\text { R Square }\end{array}$ & Sig. \\
\hline $\begin{array}{l}\text { 1. Pengandh Kepuasan Equitas (Equity Satisfaction) } \\
\text { Pelanggan Intemal terhadap Penyerahan (delivery) }\end{array}$ & $.523^{\mathrm{a}}$ & .274 & .270 & .000 \\
\hline $\begin{array}{l}\text { 2. Pengandh Kepuasan Equitas (Equity Satisfaction) } \\
\text { Pelanggan Intemal terhadap Waktu (Timeliness) }\end{array}$ & $.486^{\mathrm{a}}$ & .236 & .232 & .000 \\
\hline $\begin{array}{l}\text { 3. Penganuh Keppuasan Equitas (Equity Satisfaction) } \\
\text { Pelanggan Intermal terhadap Informasi } \\
\text { (Information) }\end{array}$ & $.528^{\mathrm{a}}$ & .279 & .275 & .000 \\
\hline $\begin{array}{l}\text { 4. Penganah Kepuasan Equitas (Eqiuty Satisfaction) } \\
\text { Pelanggan Intemal terhadap Profesionalime } \\
\text { (Professionalism) }\end{array}$ & $.532^{\mathrm{a}}$ & .283 & .279 & .000 \\
\hline $\begin{array}{l}\text { 5. Pengananh Kepuasan Equitas (Eqiuty Satisfaction) } \\
\text { Pelanggan Intemal terhadap Sikap Staf (Staff } \\
\text { Afitudude) }\end{array}$ & $.4999^{9}$ & .249 & .245 & .000 \\
\hline $\begin{array}{l}\text { 6. Pengananh Kepusasan Equitas (Equity Satisfaction) } \\
\text { Pelanggan Internal terhadap Politik Intemal } \\
\text { Organisssi (Organizational Politic) }\end{array}$ & $.165^{\mathrm{a}}$ & 027 & .022 & .020 \\
\hline $\begin{array}{l}\text { Sumber: Hasil Penelit } \\
\text { diolah) }\end{array}$ & & 20 & & data \\
\hline
\end{tabular}

Berdasarkan tabel di atas dapat diketahui bahwa pengaruh kepuasan equitas (equity) pelanggan internal terhadap variabel transaksi pelayanan yang terdiri dari enam indikator yang diselenggarakan oleh penyedia pelayanan di RSUD Padang Panjang ternyata hasil olah data statistik membuktikan bahwa masing-masing indikator tersebut terbukti berpengaruh secara signifikan. Hal ini dibuktikan oleh perolehan nilai signifikansi yang berada di bawah atau $<0.05$. Signifikan disini juga berarti bahwa pengaruh yang ditimbulkan oleh variabel kepuasan pelanggan internal terhadap masing-masing indikator dari variabel transaksi pelayanan memberikan pengaruh yang nyata dan berarti. Kontribusi pengaruh yang diberikan tentunya berbedabeda setiap indikator, namun dapat disimpulkan bahwa kontribusi yang paling besar terjadi pada indikator profesionalisme yaitu dengan kontribusi pengaruh sebesar $27.9 \%$, sementara kontribusi yang paling kecil yang disebabkan oleh kepuasan equitas pelanggan internal terjadi pada indikator politik internal organisasi, dengan kontribusi pengaruh sebesar $2.2 \%$ saja. 
Pengaruh Variabel Transaksi Pelayanan terhadap Kepuasan Equitas Pelanggan Eksternal

Pengaruh variabel transaksi pelayanan terhadap kepuasan equitas pelanggan eksternal dapat diketahui melalui penjelasan enam variabel independen, yang masing-masingnya memiliki kontribusi pengaruh yang berbeda terhadap kepuasan equitas pelanggan eksternal. Untuk memahami masing-masing pengaruh variabel independen tersebut berikut dijelaskan secara berurutan berdasarkan tabel di bawah ini:

Tabel 5. Hasil Uji Regresi Pengaruh Variabel Transaksi Pelayanan terhadap Equity Satisfaction Pelanggan Eksternal

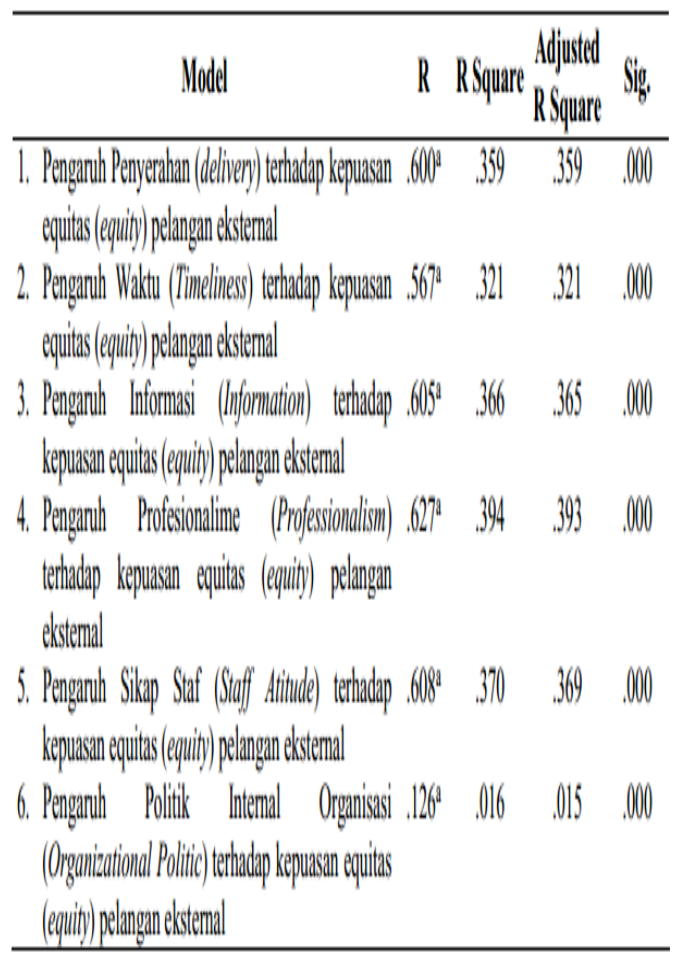

Sumber: Hasil Penelitian 2018 (data diolah)

Berdasarkan tabel di atas dapat diketahui pengaruh masing-masing indikator dari variabel transaksi pelayanan terhadap pengaruh kepuasan equitas (equity) pelanggan eksternal yang diselenggarakan oleh penyedia pelayanan di RSUD Padang Panjang. Hasil uji olah data statistik membuktikan bahwa masing-masing indikator tersebut terbukti berpengaruh secara signifikan terhadap kepuasan equitas (equity) pelanggan eksternal. $\mathrm{Hal}$ ini dibuktikan oleh perolehan nilai signifikansi yang berada di bawah $<0.05$. Signifikan disini juga mengandung arti bahwa pengaruh yang ditimbulkan oleh masingmasing indikator dari variabel transaksi pelayanan terhadap kepuasan equitas (equity) pelanggan eksternal memberikan pengaruh yang nyata dan berarti. Kontribusi pengaruh yang diberikan tentunya berbedabeda di setiap indikator, namun dapat disimpulkan bahwa kontribusi yang paling besar, terjadi pada indikator profesionalisme yaitu dengan kontribusi pengaruh sebesar 39.3\%, sementara kontribusi yang paling kecil terjadi pada indikator politik internal organisasi, dengan kontribusi pengaruh sebesar $1.5 \%$ saja.

\section{Ringkasan Analisisi dan Pengujian Model}

Model yang dikonsepkan dalam kerangka penelitian ini dianalisis pervariabel dengan regresi dan dicari perbedaan antara pelanggan internal dan pelanggan eksternal dengan menggunakan uji t-test. Hasilnya secara berurutan dikemukakan dalam penjelasan dengan sistimatika; pertama pembuktian model dan memastikan bahwa variabel transaksi pelayananan yang direncanakan, diuji terelebih dahulu kesamaan persepsi antara pelanggan internal dan persepsi pelanggan elsternal. Kedua, membuktikan adanya pengaruh signifikan kepuasan equitas (equity satisfaction) pelanggan internal dan pelanggan eksternal terhadap variabel transaksi pelayanan yang terdiri dari; Penyerahan (delivery), Waktu (timeliness), Informasi (information), Profesionalisme (profesionalism), Sikap Staf (staff attitude), dan Politik Internal Organisasi (organizational politic). Hasil ringkasan model tersebut seperti terlihat pada gambar di bawah ini: 
Gambar 3. Model Pelayanan Pemerintah Daerah yang Berkualitas (Memuaskan Pelanggan Internal dan Eksternal) Berbasis TQM

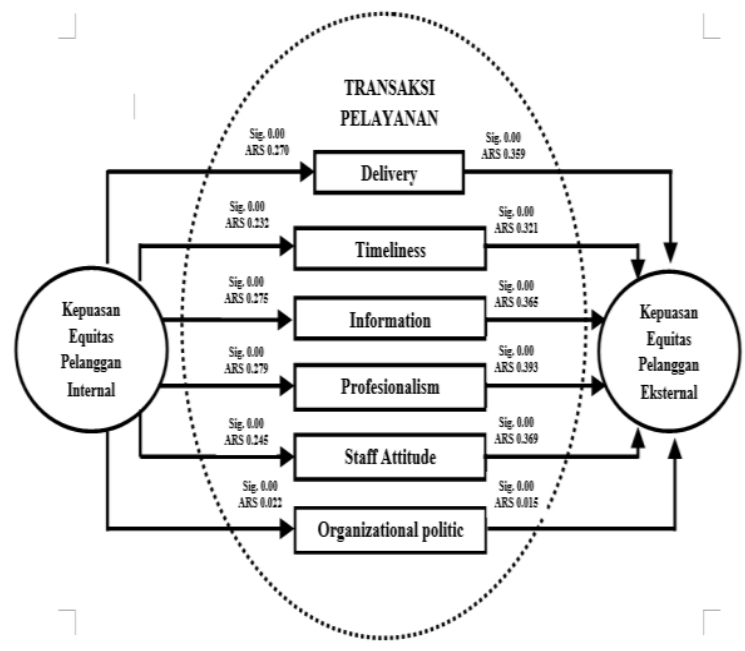

\section{PENUTUP}

Berdasarkan analisis dan temuan model di atas, maka dapat dijelaskan bahwa kepuasan equitas pelanggan internal dan pelanggan eksternal dapat diintegrasikan dalam sebuah organisasi publik yang melayani masyarakat, dengan meklarifikasi transaksi pelayanan dalam berbagai variabel. Variabel transaksi pelayanan delivery, timeliness, profesionalisme, sikap staf, terbukti kedua pihak pelanggan (internal dan eksternal) memiliki pandangan dan persepsi yang sama, sehingga dapat menjadi transaksi pelayanan yang akurat. Untuk didesain sedemikian rupa dengan indikator-indikatornya yang lebih akurat lagi supaya model ini menjadi lebih dapat dijadikan sebagai peneguh dalam kontribusinya pada TQM. Sedangkan variabel transaksi pelayanan berupa informasi yang tersedia dan keadaan politik internal organisasi, dalam model ini masih belum stabil dan diupayakan secara kritis membenahinya dan tetap diikutkan dalam uji keterandalan pada penelitian berikutnya. Berdasarkan simpulan ini, direkomendasikan dan disarankan untuk peneliti selanjutnya dapat diuji kehandalan model ini pada sektor publik yang berbeda wilayah dan sektor publiknya. Tentu dengan mencermati terus dua variabel yang belum stabil tersebut.

\section{DAFTAR KEPUSTAKAAN}

Dasman Lanin (2008). Influencing Manager Roles toward Incresing Public Servece on Local Government, The International Conference on Islamic Studies PSU Pattani Thailand $18^{\text {th }}$ August 2008.

Dasman Lanin (2010). The Effects of Bureuaucracy-Internal Politics towards Citizen Satisfaction, Journal of Administrative Sciences \& Organization, Bisnis \& Birokrasi, Vol 173, Nov 2010.

Dasman Lanin (2012). Citizen satisfaction with local government, International Conference of Public Organization, Conference, Korea University, Seoul, Korea Mey 11, 2012.

Dasman Lanin dan Adil Mubarak, "Kepuasan Diskonfirmasi Warga pada Sektor Publik: Kasus Pelayanan Kebutuhan Dasar Pemerintahan Kota Padang Panjang”. Jurnal Demokrasi, 2010, Vol. IX No. 2, hal:1-20.

Dasman Lanin dan Karjuni Dt. Ma'ani, (2015). Rekonstruksi Pelayanan Publik yang Memuaskan dan Kepercayaan Masyarakat pada Pemerintah Kab/Kota (Fundamental), UNP.

Dwiyanto, A, at.all. (2012). Reformasi birokrasi publik di indonesia, Yogyakarta: PSKK UGM.

Ginting, Paham dan Syafrizal Helmi Situmorang, 2008. Filasafat Ilmu dan Metode Riset, Usu Press, Medan.

Hallowell, R., Schlesinger, L.A. dan Zornitsky, J. 1996. Internat service quality, customer, and job satisfaction: Linkages and implication for management. Journal of Human 
Dasman Lanin, Syamsir, Boni Saputral Model Pelayanan Pemerintah Daerah yang Memuaskan Pelanggan Internal dan Eksternal Berbasis Total Quality Management

Resource Planning, Vol. 19, No. 2, pp. 20 -

31 .

Harwick, Terence dan Marty Russell. (2007). TQM: An Integrative Methodology for Doing "More with Less" in Public Service. New York. Amacom.

Hensler dan Brunell. 2003. Total Quality Management Cetakan ke-8. Jakarta: PT. Raja Grafindo Persada.

Kurniawan, \& Puspitosari (2013) Wajah Buram Pelayanan Publik, Jakarta, Malang, YAPPIKA.

Republik Indonesia, Undang Undang Nomor 25 tahun 2009 tentang Pelayanan Publik, Tambahan Lembaran Negara Nomor 5038.

Republik Indonesia, Undang-undang Nomor 22 tahun 1999 tentang Otonomi Daerah, Tambahan Lembaran Negara Nomor 3839.

Republik Indonesia, Undang-undang Nomor 32 tahun 2004 tentang Otonomi Daerah, Tambahan Lembaran Negara Nomor 4437.

Ryzin, G, G, V,. (2005) Testing The Expectancy Disconfirmation Model of Citizen Satisfaction with Local Goverment, Journal of Public Administrasion Research and Theory, Volume 16. 